\title{
PROLOGUE TO THE 2011 EDITION
}

This volume starts with the question of how to describe what was going on in Europe during the seventeenth century. The great debate of the 1950s and 1960 s about the "crisis" of the seventeenth century laid a great deal of emphasis on the "feudal" character of its processes. Most authors interpreted this to mean that there was a "refeudalization" of Europe. Volume 2 is an attempt to refute these characterizations and to insist once again that the European world-economy had become definitively capitalist during the long sixteenth century. In many ways, volume 2 is the crucial volume of the whole set in that it makes the case for a certain vision and definition of capitalism as a historical system.

Many readers have found this aspect of the work the hardest part to accept. It seems perhaps useful, therefore, to try to restate this argument more theoretically, and to indicate why I believe that what we call feudalism in Europe of the late Middle Ages is fundamentally different from the socalled second feudalism of early modern times.

The second new and important theme developed in this volume is that of hegemony. Here, too, many persons, even those sympathetic to the overall effort undertaken by world-systems analysis, have misunderstood the argument about the concept of hegemony. So it is perhaps useful also to try to restate exactly what I mean by hegemony and why I think it is a crucial concept in understanding how the modern world-system operates.

\section{Was Europe a World-Economy in the Period 1450-1750?}

The intellectual question is whether one can argue that there existed a European world-economy that was a capitalist world-economy in the period 14501750. Actually, this constitutes two questions, not one: whether Europe (or some part thereof) constituted a singular economic entity in this period with a singular axial division of labor, and whether this entity can be described as capitalist.

The argument starts from a premise, which is both conceptual and empirical. The premise is that there are phenomena known as "logistics" (Rondo Cameron's phrase), which are more frequently called in the French literature "trends séculaires." These are presumably very long cycles, consisting of an inflationary A-phase and a deflationary B-phase. That such logistics exist seems to be widely, but not universally, taken for granted in the literature of European economic historians concerning both the late Middle Ages and early modern Europe. Empirically, the dating most frequently found in the literature is as follows: 


\begin{tabular}{|l|c|c|}
\hline & Late Middle Ages & Early Modern Times \\
\hline A-phase & $1000(1100)-1250$ & $1250(1300)-1450$ \\
\hline B-phase & $1450-1600(1650)$ & $1600(1650)-1700(1750)$ \\
\hline
\end{tabular}

I am going to take the existence of these logistics and their dating as givens.

The logic of the argument is essentially the following: There are certain basic similarities between the medieval logistic and the early modern logistic, which permits us to call both of them logistics with A and B phases. However, a careful comparison of the two will show certain significant qualitative differences, such that one can deduce from these differences that Europe had an axial division of labor in the later but not in the earlier period.

The basic pattern of a logistic involves, minimally, a triple expansion and contraction of population, economic activity, and prices. They are presumed to show long-term steady rises and falls, the three moving in unison. This ignores short-run fluctuations. There has been considerable debate about which of these three phenomena is the primary determinant of the expansion and contraction. I consider this debate largely futile.

Of course, these phenomena are in turn complexes of variables. Prices do not constitute a simple overall series. The leading series in what was still an agriculturally dominant Europe has been considered to be the price of wheat. It is, however, not only that wheat prices rose and fell in absolute terms. They rose and fell comparatively to other grain prices. And cereal prices as a group rose and fell comparatively to prices for pastoral products and prices for industrial products. There were also those prices we call rents and wages. The price of wages-that is, real wages-ran in inverse relation to other price series.

The concept of economic activity is also composed of many variables, such as the quantity of commercial transactions, total production, land area in use, yield ratio, and monetary stock. These were closely related to variables of the social structure such as the agronomy, the patterns of land tenure, the degree of urbanization, and the strength of guilds.

The essential point about such logistics is that there is thought to have been a fairly systematic correlation in the cyclical movements of these variables, most of them in direct correlation with each other, but some in inverse correlation with the majority.

Generally speaking, in most analyses by economic historians there is no overall consideration of how "political" and "cultural" variables related to this schema-that is, whether there were or were not some further systematic correlations. I believe this omission to be a mistake, since I do not believe we can understand how the overall system functioned without seeing the intimate interrelation of all the arenas of social action. 
We talk of the "feudal system" to describe this period. I wonder about the word system, since feudal Europe was neither a world-economy nor a worldempire. As a "system," it can be at most described as the remains of the disintegration of the short-lived Carolingian world-empire. It is perhaps better to call it a "civilization," which would mean it was a series of small systems (or divisions of labor) linked, to the extent that they were linked, by a shared religious structure and to a limited extent by the lingua franca of Latin.

The geography of feudal Europe consisted of a multiplicity of manorial structures, each the center of a small division of labor with a surrounding zone, variously ensconced in multiple loose and wider political structures. Many of these local zones were involved in long-distance trade networks as well. But could these local zones be said to have been part of some larger economic entity, some singular division of labor? Few would claim that this was the case.

And yet, these separate zones seem to have resonated to the same pulsations, such that we talk of a logistic. Everywhere, more or less, the population began to expand in the eleventh and twelfth centuries. European agricultural production expanded, because there were both more people to engage in it and more demand for the products. Each local zone/village reclaimed wasteland at its edges (forest, swamp, moor, fen, marsh), and logically this had to be on the whole less fertile land than what they had been previously cultivating. This expansion occurred not only at the edges of each local zone, but at the frontiers of "Christian Europe" as a whole: the Crusades, the beginning of the Reconquista in Iberia, the retaking from Moslem rulers of the islands in the western Mediterranean, the "German" colonization of the "East," the Scandinavian push northward, the English push westward and northward into Celtic lands.

Because cereals were in high demand and therefore profitable, not only was "wasteland" reclaimed, but there was a shift from pasturage to arable cultivation, and from poorer grains to the richer ones (primarily wheat, secondarily rye). It became worthwhile to invest in soil nutrients and improved technology, and yields rose (despite the decline in the median quality of the soils cultivated).

Given the overall expansion and inflation, those systems of tenure that involved money rent to a landlord were seen by the landlord as less desirable. Fixed rents lagged behind inflation. Ergo, landlords sought to reduce the length of tenures, or, even better, to turn money rents into labor rents (serfdom), thereby guaranteeing the supply of labor in an expanding market. The labor could always be profitably used. On the other hand, tiny units of production might also show positive returns, and more and more persons "entered" the market as cereals producers, multiplying the number 
of economic actors and "deconcentrating" production. Indeed, one of the motives of instituting serfdom was precisely to contain this deconcentration.

The general expansion of the economy involved also, and correlatively, the expansion of the industrial sector (principally textiles and metalware) and its concentration in urban areas (which reduced the transactions costs). The urban location made possible the emergence of a reasonably strong guild structure. Overall, there was increased specialization of economic activity and expanded local divisions of labor.

Although the local division of labor could make a place for some longdistance "luxury" trade, there does not seem to have been much middledistance division of labor. The high cost of transport militated against it. In any case, local zones did not generally depend on or count on such "regional" (i.e., middle-distance) supply sources.

The politics of feudal civilization was essentially a local politics, in which the landlord/seignior sought to duplicate his economic dominance of his locality with a political dominance. This was true even when the landlord was a church figure, as many were. Kings, dukes, and counts were primarily powerful landlords/seigniors, with their own direct properties from which they drew their revenues, and secondarily war chieftains who constituted their armies out of their vassal nobility/other landlords. In the period of expansion of the economy, all landlords strengthened their political hold over their peasant populations, first of all by instituting and extending serfdom, but also by augmenting the number of their retainers. At the same time that the landlord's power over the direct producers in his locality grew, the strength of higher-ranking "rulers" (kings, dukes, counts) grew over that of the local nobility. The "households" of the rulers grew in size, and small bureaucracies came into existence. The "outer" expansion of Europe was the doing of these rulers, and enabled them in turn to become still stronger. However, one should not exaggerate. There were no really strong states, and the nobility fought back (viz. the Magna Carta of 1215 in England). But that there were "states" at all was an achievement of this period.

Culturally, this was a period of efflorescence. The material base was there and the cultural confidence as well. The "outer" expansion of Europe led to the admission of new cultural currents, which, however, at this point were well assimilated into the existing Weltanschauung. The Summa Theologica of Aquinas was just that, a summation.

The overall rise in population, the urbanization of industry, and the expansion of the political and cultural arenas meant a rise in the number and size of cities. This permitted the emergence of a small stratum of intellectuals, and the first universities were founded.

Circa 1250-1300, the expansion ended, and a long-term regression set in. Essentially, everything that had gone up went down. The "outer" frontiers receded. The Crusaders were expelled, the Byzantines reconquered Con- 
stantinople, the Moors rallied in Granada (at least for a while), the Mongols invaded from the Asian steppes.

Population declined, most notably because of the Black Death. Instead of putting new land into cultivation, land was taken out of cultivation (the Wïstungen). To some extent this was the very same land that had been brought into use two centuries earlier. This reduction in the areas under cultivation occurred in part because of the decline in population (epidemics, famines, and local wars), in part for reasons of security, in part because of enclosure and engrossing by landlords.

The price inflation was reversed. Rents declined. The price of wheat declined. There was a shift of land use from cereals either to pasturage or to vineyards (depending on the climatic zone), both because fewer cereals were needed and because cereals production required a larger workforce. The "noble" cereals gave way to the poorer ones. There was less investment in technology and in soil nutrients, and hence yields were lower.

The squeeze on seigniorial rents was further complicated by the population decline, which increased the bargaining power of the direct producers. As a result, serfdom declined, and in the end largely disappeared. On the other hand, landlords sought to compensate for their declining incomes by engrossing and enclosing land, which resulted in some reconcentration. The combination resulted in economically weakened landlords with too small a workforce, and a strengthened layer of "kulak" farmers with multisibling, multigenerational holdings. Capital moved away from investment in land.

The market for industrial goods of course declined as well. Real wages rose. In the search to reduce costs of production, industries tended to move to rural zones, primarily to reduce labor costs (a consideration that now took priority over keeping transactions costs low, especially since the number of transactions was declining).

Politically, the outcome was a decline in the local authority of the landlord/seignior over the direct producers of the locality. The rulers lost in the same fashion. The "states" began to come apart, the rulers losing their hold over the landlords/nobility. As a result of the "crisis of seigniorial revenues," there was considerably increased violence intermal to "Europe," as opposed to violence at the outer edges. There were many revolts of the peasantry, who were taking advantage of the decline in political authority. Rulers and nobles fought with each other more extensively and more intensively in a search for increased revenues. This mutual bloodletting of the upper strata weakened them still further vis-à-vis the direct producers.

Culturally, this was an era of questioning of authority, of iconoclasm, and of turmoil. The central authority of the Papacy weakened. Many new Christian religious movements, egalitarian in emphasis and quasi-heretical, spread. The cultural "center" was not holding. Intellectuals were becoming more independent. 
What should be noted, by summary of this whole logistic, is its symmetry. The economic variables went up and then went down. The social structures changed first in one direction, then in the reverse direction. The political hierarchies (landlords over direct producers, rulers over nobles) first grew stronger, then grew weaker. The central culture first affirmed itself, then was widely questioned. In addition, this symmetry was true not merely for European feudal civilization as a whole, but for the various localities. On the whole, there was not too much variation on these themes in different parts of "Europe." It was as if each local zone reproduced the general pattern. Feudal Europe seemed to be a model of what Durkheim described as mechanical solidarity.

\section{Early Modern Europe, 1450-1750}

What changed essentially in the logistic of early modern Europe is that the pattern lost a great deal of its symmetry, both the symmetry between the $A$ - and B-phases, and the geographical symmetry. There was again an expansion followed by a contraction, but the pattern of each phase was more complicated. There was once again a correlation with political and cultural developments, but the pattern here, too, was more complicated. To say that the pattern was more complicated is not to say that a pattern cannot be discerned. But to make sense of it, we have to intrude spatial patternings, or the core-periphery antinomy.

Furthermore, there was a difference in the nature of the B-phase. Whereas in the medieval logistic the B-phase was marked by a regression in population, economic activity, and prices, in the early modern period the Bphase, as measured Europe-wide, was not a regression but a stagnation or a slowdown in the rate of expansion. This can be seen quite clearly in the population figures. The big upward thrust of 1450-1600 became the flatter curve of 1600-1750. There was no equivalent to the Black Death. Furthermore, there was geographic variation. There was no significant slowdown of population growth in northwestern Europe, but there was a downturn in central Europe (primarily the result of the Thirty Years' War) and a flattening of the curve in eastern and southern Europe.

There was once again expansion in land use, not only internally to Europe, but at its outer frontiers. The A-period was the period of the great explorations and the incorporation of part of the Americas into the production map of Europe. The B-period, by contrast, marked a slowdown of further incorporations, but not a retrocession.

If we look at the land-use patterns, it is true that once again in the A-phase there was a shift toward arable production, and in the B-phase a shift away. But in detail, what happened in early modern times looked quite different from what had happened in the late Middle Ages. In the shift of land use, 
northwestern Europe moved toward a pattern of complementary arable/ pastoral production (up-and-down husbandry and Koppelwirtschaft in the A-phase, and the even more intensive convertible husbandry of the B-phase). Europe-wide, this was compensated for by maintaining specializations in either arable production or stock raising in the peripheral zones, combined with extensive export by them for the use of urban centers of northwestern Europe. Hence, this involved the creation of larger units of production everywhere-the reconstitution of great estates in northwestern Europe via more extensive enclosures and/or the reinvention of "feudal" rights, and the constitution of Gutswirtschaften and plantations in peripheral zones.

On the one hand, European commodity price gaps were reduced considerably. Whereas in late medieval times there were at least three distinct price zones, the gap between them went down from six-to-one to two-to-one between 1500 and 1800 . But, on the other hand, there was more commercial activity between the different parts of Europe, and these depended on significant differentials in the price of labor. Thus, while price gaps declined, welfare gaps began to increase. As in the Middle Ages, the A-period was one of increased specialization and the B-period of reduced specialization, but the unit within which this could be measured had changed. In the late Middle Ages, we are talking of specialization within relatively small geographical zones. In early modern Europe, we are talking of specialization within a very large geographical area.

Similar things were happening in industry. The A-period was one of urbanized industry, and the B-period one of more ruralized locations (viz. what has been described as "proto-industrialization"). In the late Middle Ages there was, to be sure, some degree of locational concentration of industry in the old dorsal spine, but this was minor in comparison to the degree to which in early modern Europe there emerged a concentration of industry in northwestern Europe. Furthermore, when there was some despecialization in the early modern B-period via the reemergence of ruralized industries in peripheral zones, this was primarily in the lowest-value textiles. The more profitable, higher-value textiles remained largely in core zones.

The geographically uneven pattern was to be found once again in the modes of labor control. Whereas in the late medieval logistic the A-period essentially meant the institution of serfdom and the B-period its dismantling, more or less everywhere, in the early modern logistic we get very clear geographic variations. The core zone, with more specialized agriculture, did not move back to serfdom, but rather toward a triadic model of landlord, fermier, and subtenant direct producer. This became even more accentuated in the B-period, with the "disappearance" of the yeoman farmer. Most agricultural production was placed for sale on the market.

In the periphery, large-scale units with coerced cash-crop labor emergedserfs on Gutswirtschaften in eastern Europe; slaves and, for a while, indentured 
laborers on plantations in the extended Caribbean; successive models of coercion for labor of indigenous peoples in American mines. A significant part of this production was for the market-sold to the core zones in the A-period, sold to "regional" markets in the B-period when the core-zone markets were "closed" to them. These areas also produced for their own needs.

When the profitability of the large estates of the peripheral zones declined in the B-period, the owners compensated by increased exploitation of the labor force. It should be noted that there was probably a steadily increasing pressure on the workforce with the establishment of the capitalist worldeconomy, shifting from the medieval norm of sunup to noon to the early modern pattern of full-day work, which was de facto further extended in peripheral zones in the B-period.

Furthermore, when the specialization moved from the level of intralocal zones to intra-European, it was possible to have more than two zones. In fact, a third zone appeared, the semiperipheral zone, with its own distinctive patterns - the prevalence of sharecropping, the role as intermediary location in the trading patterns of the world-economy, a combination of core and peripheral economic activities, state structures and wage levels (over the long run) in-between the patterns of core and peripheral regions.

There was one last major difference in the economic landscape of the early modern logistic from that of the medieval logistic. Braudel's upper story of monopolizing multisector enterprises, cutting across political boundaries, emerged during the early modern period as key economic actors, becoming the key locus of the accumulation of capital.

The politics of a capitalist world-economy were quite different from the politics of a feudal civilization. The states became the key unit of political organization, rather than the local unit with a manor at its center. The states began to take their modern form. The first problem was the creation of significant bureaucracies, both civil and military, such that the rulers were no longer primarily dependent for their revenues on their personal landholdings, but instead had a taxation base. As part of the transition from the feudal system of a ruler's household to a fully developed bureaucratic system of the kind that Weber described, the states of early modern Europe invented an intermediate system in which the bureaucrats were partially independent entrepreneurs, engaged in "sharecropping" the state. These were the systems of venality of office and tax-farming. As transitional mechanisms, they proved remarkably resilient and successful.

The states were located within, and constrained by, a new institution, the interstate system, which crept surreptitiously into existence during the sixteenth century and was consecrated only in 1648 with the Treaty of Westphalia. In theory, all the states within the system were sovereign, independent, and equal. In practice, there was a hierarchy of state power, one that tended to correlate with the position of the state in the world-economy. This com- 
bination of the greater importance of states and the creation of an interstate system modified seriously the impact of each phase of the logistic on the distribution of power.

In the medieval logistic, in the A-period there had been an increase in the power of the seigniors over the direct producers and of the rulers over the nobility, and in the B-period a corresponding decline. In the early modern logistic there was an increase in the power of the ruler over the nobility in the core zones (absolutism) but a steady decrease of such power in the periphery (e.g., the enormous increase in the power of the Polish Diet), with the situation in semiperipheral states being in-between. The story is somewhat different with regard to seignior/dependent relations. Whereas the power of the seigniors clearly grew in the periphery, especially during the B-period, the situation was more balanced in the core zones, where the rulers were seeking to gain direct political control over their subjects, and to gain an ever larger portion of their monetary payments. In order to do this, they had to try to diminish the political power of the seigniors over the direct producers. While this was a steady process in the A-period, it slowed down in the B-period. Nonetheless, one may argue that, in general, seignior/ dependent relations evolved in the direction of the lessening of seigniorial power - a process that would bear its fruit only in the nineteenth century, when the citizen finally came fully under the direct control of the state without any significant local intermediaries. This was not, however, true of peripheral zones, and is not even to this day.

One other political difference is to be noted. The development of a capitalist system brought with it, obviously, a growing sector of bourgeoisie. Once again, this was not at all evenly spread throughout the European worldeconomy. The bourgeoisie was disproportionately located in the core zones and virtually eliminated in peripheral zones (at least bourgeois of local origin). Furthermore, as a result the national politics of each zone changed correspondingly.

Finally, briefly, in the cultural arena, the same spatial differentiation may be noted. Whereas feudal Europe was up to a point culturally homogeneous (at least in terms of the dominant cultural entity, the Church), early modern Europe developed a major religious schism, which over the period comes to correlate highly, albeit imperfectly, with the basic economic schism. It does not seem that the correlation is accidental.

The early modern logistic does repeat itself. Of course, there are certain processes of development of the system-spatial expansion and incorporation of new zones into the world-economy, the repeated demonopolizations and the search for new technologies on which to base new monopolies, the steady processes of urbanization, proletarianization, and political co-optationswhich seem to change their shape but do not in fact change the basic spatially asymmetric, inegalitarian structure of the world-system. 
This then is the basic difference between the two logistics: symmetry versus asymmetry, multiple local divisions of labor versus a singular world-economywide division of labor, an $\mathrm{A} / \mathrm{B}$ that is up-down versus one that takes a steplike form (or a ratchet effect). This is what Durkheim calls the difference between mechanical and organic solidarity. To be sure, the crucial debate concerns the degree to which the relatively slight differences within Europe at the beginning of the long sixteenth century (and subsequently within the geographically widening capitalist world-economy) became a much wider gulf by the twentieth century. Some argue that this was only partially true, the quantitative difference being insufficiently great. This position seems to be hard to sustain. Others argue, however, that it became true only in the nineteenth century or even only in the twentieth. It is of course possible to make such a case, since the polarization has been steady and increasing in rate. But it seems implausible to date the life of an organism only from its most fully ripened stage, the point at which it is about to die. Youth has its claims to reality.

\section{The Concept of Hegemony in a World-Economy}

One of the key concepts in world-systems analysis is that there are two different kinds of world-system that the world has known up to now-a worldeconomy and a world-empire. A world-empire is defined as a structure that has a single overall political structure and a single overall division of labor. Han China and the Roman Empire are two good examples of a world-empire. The concept of hegemony refers to an attribute that a state may have in the interstate system of a world-economy.

A hegemonic power is quite different from a world-empire. The political superstructure of a world-economy is not a bureaucratic empire but an interstate system composed of allegedly sovereign states. And a hegemonic state is not simply a strong state, not even simply the strongest single state within the interstate system, but a state that is significantly stronger than other strong (strong, not weak) states. This describes a situation that has occurred repeatedly but not at all continuously. That is to say, there are periods when a hegemonic power exists within the interstate system of a world-economy, and others when there is no hegemonic power but rather a "balance of power" among multiple strong states.

What does it mean to say that there exists a hegemonic power? It means that one state is able to impose its set of rules on the interstate system, and thereby create a world political order as it thinks wise. In this situation, the hegemonic state has certain extra advantages for enterprises located within it or protected by it, advantages not accorded by the "market" but obtained through political pressures.

I think it is useful to think of hegemony not as a structure but as a pro- 
cess in time. Furthermore, I think it is a process that doesn't have just two moments in time (rise and fall) but, by analogy with how Schumpeter conceived of Kondratieff cycles, four moments in time. If one starts the story when there is an uncontested hegemonic power, the first moment occurs in the period immediately thereafter. It is the moment of the slow decline of the hegemonic power, during which two powers emerge as contenders for the succession. The moment after that is when the decline has become definitive. We can think of this second moment as one in which there is a "balance of power" in the world-system. During this moment, the two contenders for hegemony struggle to secure geopolitical and world-economic advantage. The third moment is when the struggle becomes so acute that order breaks down and there is a "thirty years' war" between the contenders for hegemony. And the fourth moment is when one of the contenders wins definitively and is therefore able to establish a true hegemony-until, of course, the slow decline begins.

Up to now, there have been three hegemonic powers in the history of the modern world-system. The United Provinces was the hegemonic power in the mid-seventeenth century, briefly, from 1648 to the 1660s. The United Kingdom was the hegemonic power for a slightly longer time in the nineteenth century, from 1815 to 1848 , perhaps a little longer. The United States was the hegemonic power in the mid-twentieth century, from 1945 to $1967 / 1973$.

After Dutch hegemony, the two powers contending for the succession were England and France. After British hegemony, the two powers were the United States and Germany. After U.S. hegemony, the two powers were an emerging northeast Asian structure (Japan-Korea-China) and a still only partially stabilized European Union.

\section{Slow but Inevitable Decline of the Hegemonic Power}

Hegemonic powers decline because they cannot sustain forever their quasi monopoly of world geopolitical power. This is because in pursuing their economic interests, they eventually undermine their economic advantages. And in pursuing the maintenance of their political-military power, they eventually undermine their political-military power.

The ambiguity of the relationship of the hegemonic power and its allies is clearest in the economic sphere. On the one hand, the hegemonic power seeks to restrain the economic strengthening of its allies in order to maintain its own "extra" advantage. On the other hand, the hegemonic power needs markets, and it also needs allies strong enough to help keep the "enemy" at bay. Both of these requirements inevitably lead to the economic strengthening of the allies. The productive superiority of the hegemonic power over other strong powers disappears or at least is much diminished.

So inevitably, hegemony undermines itself, first of all economically-a 
decline caused directly by the economic strengthening of the allies. In this period, the declining hegemonic power has to use its politico-ideological wiles to maintain economic extra advantage, something that it can do at first but that becomes increasingly difficult as the years go by, particularly insofar as the "enemy" seems to become less dangerous. The legitimacy of the extra advantage begins to be questioned. The hegemonic power has to resort to asserting the validity of its ideology. And the very act of asserting the validity of an ideology not only serves as proof of its decline but has a further negative impact on its appeal.

Furthermore, as part of its efforts to maintain the world order it has established, the hegemonic power begins to invest much in military structures. It finds that, from time to time, it needs actually to use its military forces. Using the military is costly and diverts finance from economic investments.

To be sure, in this period the hegemonic power still has immense military power. But in the period of real hegemony it seldom needed to use the military power, because everyone assumed it was there and was overwhelming. In the period of decline, it begins to need to use it, and even if it wins the military struggles, the very use of the military power undermines its longrange effectiveness. It means that others are daring to challenge the hegemonic power militarily. And one dare leads to another.

\section{The Balance of Power}

There seem to be some patterns in what happens as the two contenders for hegemonic succession grow stronger and more assertive. In each case up to now, one contender has been primarily land based and the other primarily sea based (or today, sea/air based). And in the two first hegemonic cycles, the land-based power sought to gain dominance by transforming the worldeconomy into a world-empire. Napoleon tried to conquer all of Europe, and Hitler tried to conquer the world. In response, the sea-based power sought to become not an imperial but a hegemonic power.

To do this, the sea-based powers constructed grand alliances, and first of all an alliance with the erstwhile hegemonic power-England with the United Provinces, the United States with Great Britain. By analogy, we might expect that the putative northeast Asian structure will seek an alliance with the United States. In the past two cases, the erstwhile hegemonic power became the junior partner of the rising sea (or sea/air) power.

In the beginning, the rising sea-based power has tended not to have a significant land army, which would be constructed only at a later stage. The absence of an army at this early stage had one clear advantage: it saved a great deal of money, money that was invested instead in the economic infrastructure of the country, enabling it to win the crucial struggle to be the most competitive power in the sphere of production for the world market. 
In the previous two instances, productive advantage led to commercial advantage, which in turn led to financial advantage. It was the point at which the rising power had all three advantages that corresponded to the moment of true hegemony. This sequence in the Dutch case is discussed in this volume. It was also true, as described for the Dutch and as would again be the case for the British, that decline repeated the same order-the declining hegemonic power first losing productive advantage, then commercial advantage, and guarding financial advantage the longest.

The process of decline is not disastrous for the erstwhile hegemonic power. It remains for a long time the strongest country, with all the prestige that has accrued to it as the hegemonic power. It remains normally an extremely rich country, even if it is comparatively less rich than before. There is still a lot of fat in its national wealth, which allows its residents to lead a very comfortable existence. The decline is a slow process at first, and of course there is an attempt to deny its reality, to others and even to oneself. But eventually decline takes its toll.

This period of decline is not one in which the previous hegemonic power is weak. Quite the contrary. It remains for a long while the most powerful country in the world, politically and militarily (but no longer economically), but it is no longer hegemonic. That is, it begins to benefit less and less from the "extra" advantages of hegemony. This period of slow but steady decline can be considered a period of slow but steady disintegration of world order, the previous order.

It was during the period of the "balance of power" that the declining hegemonic power began to invest significantly in the economic activities of the rising power to which it was becoming allied as a junior partner. It thereby preserved for a time its strength in the financial sphere, and found a fruitful outlet for its surplus capital.

Disorder in the world-system tended to grow. The erstwhile hegemonic power showed itself to be incapable of ensuring order. The two rivals for the hegemonic mantle became more and more vigorous in their attempts to ensure their primacy by acquiring appropriate geopolitical alliances and trying to create the bases for new leading products on the basis of which they could create powerful monopolized sectors of production. The "balance of power" began to seem unacceptable to both rivals. Order then broke down definitively.

\section{The "Thirty Years' War"}

Eventually, we reached the moment of total disorder, the moment of "world war" or, as I prefer to think of it, of a "thirty years' war." The original Thirty Years' War was from 1618 to 1648 , out of which the United Provinces emerged hegemonic. The second one was the Revolutionary/Napoleonic 
Wars of 1792-1815, out of which the United Kingdom emerged hegemonic. And the third was the period 1914-1945, out of which the United States emerged hegemonic.

There was a relatively common pattern in the three "thirty years' wars." Each of them involved warfare throughout most of the relatively welldeveloped areas of the world-economy of the time, and each was immensely destructive to the physical infrastructure and to the populations in the area. These "world wars" were not, however, continuous. They were conducted, if you will, in fits and starts.

Each "thirty years' war" was ambiguous ideologically. The Dutch allied with Catholic powers. Great Britain allied with the most autocratic powers in Europe. The United States allied with the Soviet Union. During each "thirty years' war," the emphasis was not on ideological purity but on defeating the other contender. In each case, the eventual hegemonic power developed a strong land army during the course of the world war, and by the end this land army of the winning rival had become a significant element in its military victory. And in each case, the erstwhile contender was definitively defeated and lost its vigor (at least for a while), both militarily and economically, as well as politically of course.

Finally, in each case, the hegemonic victor was largely spared from physical destruction during the war. The combination of being spared from destruction and the wartime development of the economic infrastructure meant that, at the end of the world war, the hegemonic power had an enormous economic advantage over all other major powers. It could produce the most profitable products of the era more efficiently than all othersnot only the producers in peripheral zones but producers in other erstwhile or future core zones.

\section{True Hegemony}

The end of the world war signaled the beginning of real hegemony, the last stage in the cycle, or the first. Weary of war, weary of the breakdown of order, weary of political uncertainty, the world welcomed, or seemed to welcome, the "leadership" of the now hegemonic power. The hegemonic power offered a vision of the world. The Dutch offered religious tolerance (cuius regio, eius religio), respect for national sovereignty (Westphalia), and mare $l i$ berum. The British offered the vision of the liberal state in Europe based on a constitutional parliamentary order, political incorporation of the "dangerous classes," the gold standard, and the end of slavery. The United States offered multiparty elections, human rights, (moderate) decolonization, and the free movement of capital.

These visions were ideology, not necessarily practice. As Sir George Downing said in 1663 about the Dutch vision: "It is mare liberum in the British 
seas, but mare clausum on the coast of Africa and the east Indies." (That is where the Dutch held the advantage.) Hegemonic powers have never allowed ideology to interfere with the pursuit of their interests. Nonetheless, these visions were the basis on which the hegemonic power claimed legitimacy for its hegemonic position, and this vision no doubt played a major role in its ability to maintain world order.

In the period of true hegemony, it was essential for the hegemonic power to construct both an "enemy" to its world vision and a network of alliances. It was less that the alliances were constructed in order to combat the enemy than that the enemy was constructed in order to control the allies. The hegemonic power sought to ensure that the allies bent their immediate economic interests to those of the hegemonic power, thus creating those "extra" advantages that are the purpose and perquisite of hegemony.

The Dutch forged a Protestant alliance with England against the French. The British in the period after 1815 forged the Entente Cordiale with France against the authoritarian trio of Russia, Austria, and Prussia. And the United States created NATO (and the U.S.-Japan Defense Treaty) against the Soviet Union and the Communist bloc. In each case, the allies were economically hampered by the alliance, at least until the period of decline of hegemonic power (and to some extent even then).

The leadership that the hegemonic power offered was not only politicoeconomic but cultural as well, and not only in the arts but, more important, in the structures of knowledge. This was true of the Dutch, who provided for a long time the locus where intellectuals could congregate when forced into exile from their own countries. How the British and then the Americans forged a certain version of the structures of knowledge is something to which volume 4 devotes much space. This control of the cultural sphere is, along with control of the financial sphere, the last redoubt of hegemonic advantage. But it, too, passes in the course of time.

Hegemony is a critical mechanism in the functioning of the modern worldsystem. The cycles of hegemony are crucial markers in the cyclical rhythms of the capitalist world-economy. In a sense, it is the rise and fall of the hegemonic powers that prevented the transformation of the world-economy into a world-empire-something that had happened regularly before the creation of the modern world-system. The mechanism of hegemony allowed the modern world-system to become the first world-economy in the history of humankind to survive, flourish, and expand to encompass the entire globe. Without it, capitalism as a historical system would not have been able to survive, and thereby to transform the world.

${ }^{1}$ Cited in Pieter Geyl, The Netherlands in the Seventeenth Century, vol. 2, 1648-1715 (London: Ernest Benn, 1964), 85 . 
This page intentionally left blank 